IRA-International Journal of Education \& Multidisciplinary Studies

ISSN 2455-2526; Vol.14, Issue 03 (March, 2019)

Pg. no. 45-53.

Institute of Research Advances

Institute of

http://research-advances.org/index.php/IJEMS

\title{
Teach Them to Observe all that I Have Commanded You: Great Commission or Omission?
}

\author{
Francisca Wavinya Ngala $^{1 \#}$ \& Rosemary Wahu Mbogo ${ }^{2}$ \\ ${ }^{1,2}$ Lecturer, Africa International University, P.O. BOX 24686-00502, Karen, Nairobi, Kenya. \\ \# corresponding author. \\ Type of Work: Peer Reviewed \\ DOl: http://dx.doi.org/10.21013/jems.v14.n3.p2
}

\begin{abstract}
How to cite this paper:
Ngala, F.W., Mbogo, R.W (2019). Teach Them to Observe all that I Have Commanded You: Great Commission or Omission? IRA International Journal of Education and Multidisciplinary Studies (ISSN 2455-2526), 14(3), 45-53.doi: http://dx.doi.org/10.21013/jems.v14.n3.p2
\end{abstract}

(C) Institute of Research Advances.

This work is licensed under a Creative Commons Attribution-Non Commercial 4.0 International License subject to a proper citation to the publication source of the work.

Disclaimer: The scholarly papers as reviewed and published by the Institute of Research Advances (IRA) are the views and opinions of their respective authors and are not the views or opinions of the IRA. The IRA disclaims of any harm or loss caused due to the published content to any party.

Institute of Research Advances is an institutional publisher member of Publishers International Linking Association Inc. (PILA-CrossRef), USA. The institute is an institutional signatory to the Budapest Open Access Initiative, Hungary advocating the open access of scientific and scholarly knowledge. The Institute is a registered content provider under Open Access Initiative Protocol for Metadata Harvesting (OAI-PMH).

The journal is indexed \& included in WorldCat Discovery Service (USA), CrossRef Metadata Search (USA), WorldCat (USA), OCLC (USA), Open J-Gate (India), EZB (Germany) Scilit (Switzerland), Airiti (China), Bielefeld Academic Search Engine (BASE) of Bielefeld University, Germany, PKP Index of Simon Fraser University, Canada. 


\begin{abstract}
Members of any congregation professing Christianity are a flock that needs to be looked after as commissioned by God. Faith in Christ often brings them together to strengthen one another by listening to the word of God and receiving God's blessings through the minister/pastor/priest among others. These servants, therefore, have the obligation to mould and form a spirituality of their congregations as they patiently wait for the second coming of Jesus Christ by teaching them. Therefore, this paper endeavoured to interrogate the Christian curriculum of selected churches with respect to spiritual formation among the faithful. The descriptive survey design was used for the study. Systematic random sampling was used to select 945 participants. Questionnaires were consequently distributed to the 945 members. Overall, 538 questionnaires were returned and analyzed to provide useful information. The Statistical Package for the Social Sciences (SPSS) was used to analyze the data and t-tests performed. The study findings revealed that the servants of God use Christian education as an approach towards the great commission of God in enhancing spiritual formation on the faithful. The findings suggest that the servants are working towards strengthening spirituality and hence Christianity of the faithful in their churches. Despite the omission of the great commission over a long time, churches are now embracing curriculum tailored to addressing specific objectives geared to enhancing Christianity and strengthening faith among the faithful.
\end{abstract}

Keywords: Discipleship, Spiritual formation, Commission, Omission, Education and Christianity.

\title{
Introduction
}

The realization that what the church seems to have neglected is basically the most essential thing that constitutes the business of the church of Christ 'Discipleship' is somehow disturbing [1,2]. The church has not fared well in teaching members to obey all that Jesus taught as evidenced by the apparent lack of transformation among professing Christians. According to Maura, Mbugua and Piper [3], preachers are preaching false doctrine, such as prosperity gospel which Paul would call another gospel in line with Gal 1:6-12. The church has really fallen short of attaining the standards that Jesus taught and something urgently needs to be done to salvage the state of the church.

The situation is even more critical because Jesus said that a disciple cannot be greater than his teacher (Matt 10:24) and if the members are to be disciples, then their teachers must be following Jesus, and consequently if the teachers are not following Jesus, then chances are very high that the students will not be following Him.

How can it be that Christians and non-Christians are not different in terms of character and value systems? Willard [4] seems to have gotten it right in his book, The great omission. In this book, he plainly describes the omission of intentional discipleship in the contemporary church as a great omission. According to him, the attitudes of Christians show no difference with those held by non-Christians. It is even worse when he observes that those who purpose to live holy lives are ridiculed as fanatics. The number of people in today's church who believe that they can be Christians without being disciples is increasing. Willard says that church leaders are to bear the greatest blame for misunderstanding the great commission. Could it then be interpreted that there is a shortage of teachers who model Christian lifestyle? Willard narrows down on teaching as the thread that is missing in the evangelical life today and according to him, the hard nut to crack is that the church is not teaching members to obey everything Jesus taught [5]. So then who should teach the believers to obey all that Jesus taught, and what are the qualities of the teacher? Wilhoit[6] notes that:

The values that teachers carry into the classroom matter far more than the curriculum they follow. . . because a teacher's values will be caught by the student, even if not overtly taught. The teacher's values control the 'hidden curriculum', the shape, feel, and hidden agenda of the class, which may confirm or deny the material which is explicitly taught [p.12].

Paul was a great role model of Christlikeness [7](). Scripture supports the idea of having role models to follow, as long as the models themselves are following Christ (1 Cor. 11:1;1; The 1:6; 2 The 3:9; Phil. 3: 17-18; 1 Pet 3:517.4:15-19; 1Tim 4:12-16). If discipleship is to be done the Bible way, then the teachers will not only be mentors but also role models. Whatever the teacher teaches in the written curriculum must be reflected in his/her lifestyle so that his/her students may emulate. The disciple will follow the teacher, as the teacher follows Christ. This suggests that the behaviour of the teacher is key to the spiritual transformation of the disciple in addition to the curriculum and the strategies he/she uses. 
Research studies from the West have demonstrated that disciple-making is neglected in the church leading to lack of transformation among confessing Christians and the solution lies in discipleship [8,5]. This paper adds an African perspective to the literature on discipleship and reinforces the value of assessment of spiritual transformation since assessment is an integral part of any training programme but seemingly not emphasized in the literature on discipleship. For discipleship programmes to be effective there will be a need for assessment of spiritual transformation on a regular basis. Lifeway's[9] research discovered that only 45\% of Assemblies of God churches in the USA regularly evaluate the progress and spiritual growth of their members. Stirred up by these ideas, the authors in this paper sought to find out the role of formal discipleship curriculum in the teaching ministry of the church with respect to spiritual formation among the faithful.

\section{Literature Underpinning}

The last words of a departing person are very significant especially in an African setting where one's final instructions must be properly comprehended to fulfil their wishes. This was the case with Jesus when his ministry on earth was completed. He left the final instructions contained in the Great Commission (Matt 28:19-20). The church was commanded not only to evangelize but also to make disciples and teach people to obey all that Jesus taught them. The church seems to have done well in evangelism as evidenced by large multitudes of Christians. Unfortunately, the other part of the Commission that calls upon the church to make disciples and teach people to obey the teachings of Jesus seems to have been ignored. This has resulted in a lack of transformation among confessing Christians. As noted earlier, Willard [4] says that the church is doing the Great omission, not commission. Jesus wanted people to be made into disciples and be baptized, then the disciples were to be taught to obey all that $\mathrm{He}$ had commanded and this is what can be attributed to the growth and effectiveness of the early Christians.

However, in place of Christ's plan, historical drift has substituted 'make converts (to a particular faith and practice) and baptize them into church membership). This causes two great omissions from the great Commission to stand out. Then we also omit, of necessity the step of taking our converts through training that will bring them ever increasingly to do what Jesus directed. These two omissions are connected in practice into one whole. Not having made our converts disciples makes it impossible for us to teach them how to live as Christ lived and taught [4, p.6].

The church has dichotomized evangelism and discipleship and this has not been without consequences as seen in quantitative (multitudes) of Christian growth which is not proportional to qualitative growth of (quality) of the Christianity. Evangelism should be the beginning point, after which those that have been witnessed to, are then discipled towards Christ-likeness. This is what will result in the spiritual formation of the faithful. The church has forsaken its biblical mandate as given in the great commission and if Christianity will be anything worth it's salt, then the church must go back to the Great Commission and do it in totality[10, p.26].

Converts to Christianity must be discipled through teaching them to obey all the teachings of Jesus. Jesus himself made disciples who were transformed, and that is why Christianity spread quickly and had a lot of impacts. Today's Christians have very little impact as a result of the lack of transformation and proper leadership. Ogden [8], reports that there is a lot of superficialities especially in the "incongruity between numbers of people who profess faith in Jesus Christ and the lack of impact on the moral and spiritual climate of our times".Barna[11] says that discipleship does not happen in a vacuum. It has to be accomplished in cooperation with other followers of Christ. He argues that it requires an intentional and strategic thrust to facilitate spiritual maturity and that the church should develop a philosophy that emphasizes discipleship and provide the process for facilitation of spiritual maturity.

\section{The Relationship between Discipleship and Christian Education}

Barna[11] defines discipleship as an activity that guides individuals to become spiritually mature zealots for Christ who in turn reproduces equally passionate mature followers of Christ. Christian education in this paper refers to training in the context of the church that focuses on Christian faith formation through the use of scripture and in which everything is focused on God as revealed through the Lord Jesus Christ by the help of the Holy Spirit. According to Barna[11], the terms discipleship and Christian education are closely related and they build on each other to create a fully mature follower of Jesus Christ. Education is the process through which discipleship is achieved. This means that without Christian education, discipleship cannot happen. It is Christian education that prepares and teaches one for a lifetime of becoming a complete and competent follower of Jesus. The Great Commission includes the two terms. Converts to Christianity were to be prepared to become disciples by teaching them to obey all that Jesus had commanded. 
It is quite unfortunate that today Christian education is not taken seriously even in the church. It is not surprising to find churches that do not have a Christian education department not to mention the absence of trained personnel to handle the teaching ministry of the church. Christian education as a discipline has become so trivialized that many schools have dropped it from their curriculum. In addition, what was once so important aspect of church life is now seen by many to be irrelevant and innocuous. But rather than simply bemoaning the current state of Christian education, we are more responsible if we ask what the Bible teaches about teaching. If scripture values teaching ministry the church must value it as well. If teaching is critical from a biblical perspective, it must also be critical in our perspective [12, p.23]. This will be a foundation towards training men and women in the church, especially in the twenty-first century towards the achievement of the vision 2030.

Nonetheless, the failure of the church to take Christian education seriously is directly proportional to the poor state of discipleship in the Church. The Church must teach Christians to obey all that Christ taught. Evangelization alone will not cause progress in the church because teaching is a vital component of church ministry. This is demonstrated by Paul who believes that the ability to teach is a major qualification of a church leader (1 Tim 3:2) and that whatever he taught, Timothy should entrust it to reliable men who are qualified to teach others (2 Tim 2: 2). Teaching in the church should not be an option or one of the things but the main thing so that Christians will be the same thing as disciples of Jesus.

Barna[11] identifies nine barriers to discipleship as lack of clear measurable definition of spiritual success;defining discipleship as head knowledge rather than complete transformation;failure to teach people in a systematic way through strategic learning and development process customized for the student;lack of accountability for what people say, think or do; promoting programmes and not relationships with people;the failure of small groups to provide comprehensive spiritual nurture; the failure of the church leaders to be zealous for spiritual development of the people;focussing attention on adults and not children who provide the greatest return on investment (he emphasizes that once children reach the age of 12 it becomes difficult to change how they think and behave); and diversion of the best ministry leaders to ministries other than discipleship. If these factors can be taken seriously by the church leaders, effectiveness would easily be achieved and this would enhance the spiritual transformation of the faithful [p.88].

\section{Theoretical Underpinning: Observational Learning}

The observational learning theory according to Bandura [13] proposes that people behave the way they behave because they see people they respect being rewarded for their behaviour. This theory has implications for the teaching ministry of the church in the African context with a focus on Christian leadership. The teacher should improve his/her status with students, model preferred attitudes and skills and use others as models to be imitated [14, p.81]. The teacher should be exemplary. He should be worthy of imitation. Teachers are expected to provide excellent examples to those whom they teach. This, in turn, produces excellence in the students [14]. Christ-likeness is to be modelled by the teachers. Teachers who do not model what they teach can be likened to the Pharisees whom Jesus referred to as blind guides (Matt 15; 14; 23:24). Paul challenged the Corinthians to follow his example as he follows the example of Christ (1 Cor 11:1). This in itself portrays the kind of leadership that Christian leaders in the church should look after.

Most human behaviour is learned observationally through role modelling: from observing others, one forms an idea of how new behaviours are performed, and on later occasions, this coded information serves as a guide for action. Because people can learn from example, at least in approximate form, before performing any behaviour, they are spared needless errors [13].

The observational learning theory is relevant because while Christian values will be new behaviours to converts, the presence of role models from whom they can imitate will cause a change in behaviour as they get assimilated to the Christian community. Bandura [15] supports spiritual modelling in stating that congregations provide several models of behaviour to reinforce lifestyles patterned on them. In the absence of leaders who act as role models, spiritual concepts can be very abstract and people may not know how to apply them. This concurs with Oman and Thoresen[16] who say:

Spiritual modelling is proposed as an important but neglected component of traditional religious involvement as well as of many spiritual practices. Religious and spiritual traditions often portray 
spirituality as primarily 'caught not taught', as transmitted through formal and informal observation of persons serving as exemplars of how to live a spiritually meaningful life [p.149].

Thus, the authors recommend that spiritual modelling and observational learning are areas that should be taken seriously in research. From the preceding discussion, it is evident that Christian leadership plays a significant role in spiritual formation. It is therefore against this belief that the authors sought to interrogate the role of Christian curriculum in the church with an aim to transform faithful towards Christ's command.

\section{Methodology}

The study was focused on assessing the role of Christian education in relation to spiritual transformation. Redeemed Gospel Churches in Kangundo Sub County, Machakos County formed the area of focus in which inquiry was conducted. In conducting the study, descriptive survey design which utilized the cross-sectional approach to data collection was used. The survey design as recommended by Gay, Mills and Airasian[17] "determines and describes the way things are" [p.159], which was the case in this study. The cross-sectional approach was adopted to measure current attitudes of participants within the specified time [18] (. Samples were drawn from members in the selected churches in Redeemed Gospel Church in Kangundo District using systematic random sampling techniques and questionnaires which were the key data collection instruments were administered to them to get the required information. The findings were therefore generalized to represent all the members of the Redeemed Gospel Church in KangundoSub County. The Redeemed Gospel Church in Kangundohad a total of about 70 churches with an estimated population of over 10,500 members. The average population of most churches was about 150 members. The member's education levels were varied, such that some could read and write English well while others required assistance with reading and writing. Informal preliminary studies in the Redeemed Gospel Churches of Kangundo Sub County revealed that members were exposed to opportunities to benefit from mentoring relationships, role models in the faith, formal curriculums and small group fellowships but whether the opportunities were utilized, depended on individual choices, specific local churches and the length of time a member has been a Christian.

The study therefore targeted 30\% (minimum proposed sample size by Best and Khan [19, p.18]of the 70 churches obtaining a sample size of 21 churches which yielded a sampling interval of 3 . From the list of all the 21 churches, seven was used as the random starting number after which every third church to the $21^{\text {st }}$ had been selected. The participants were selected systematically from church membership registers. From average number (150)of church members in most churches, a sample of 30\% which gave 45 participants from each church, producing 3 as the sampling interval was obtained. Five was picked as the random starting number and then picked every third number till all the required 45 participants were selected from each church. Table 1 presents the sampling matrix for participants.

\section{Table: 1 Sampling Frame}

\begin{tabular}{lll}
\hline & Churches & Members \\
\hline Target population & 70 churches & $150 * 70(10,500)$ \\
Sample churches & $30 \% * 70$ & $150 * 21(3150)$ \\
Sample participants & $30 \% * 150 * 21$ & $45 * 21(945)$ \\
\hline
\end{tabular}

The authors considered various instruments upon which the inquiry was made. The instrument chosen was the Spiritual Assessment Inventory (SAI) with various scales including awareness scale, disappointment scale, grandiosity scale, instability scale impression management scale and realistic acceptance scale.All were tested for internal consistency and recorded coefficients of $(0.948,0.907,0.864,0.856,0.824$ and 0.906$)$ respectively. All the subscales depicted that the value of Cronbach's Alpha was above the value of 0.7 thus the study's instrument was reliable.

In seeking the answer to the study objective, a hypothesis was drawn which was tested against the spirituality scales to establish whether differences existed in spiritual transformation between those members who were discipled using the four strategies and those who were not.

$\mathrm{H}_{0}$ : There are no significant differences in spiritual transformation among the members who have gone through a formal discipleship curriculum (new believers' class) and those who have not. 


\section{Results and Discussion}

The study aimed at conducting an interrogation of the formal discipleship curriculum thus the participants were expected to respond to various questions to achieve the objective. The questions had only two options: 'Yes' and 'No'. Table 2 contains findings of the analysis for formal discipleship curriculum.

Table2. Formal Discipleship Curriculum

\begin{tabular}{lll}
\hline Response & Frequency & Percent \\
\hline No, I have not gone & 208 & 38.7 \\
Yes, I have gone & 330 & 61.3 \\
\hline Total & $\mathbf{5 3 8}$ & $\mathbf{1 0 0}$ \\
\hline
\end{tabular}

The respondents were asked whether at any one time they had gone through a formal discipleship curriculum (new believer's class). Results in Table 2reveals that majority of the respondents who were $61.3 \%$ said yes while $38.7 \%$ said no. This implies that majority of the Redeemed Gospel Church members had gone through a formal discipleship curriculum which was expected to boost their spiritual growth and transformation. The results of a formal discipleship curriculum were statistically tested against the six subscales of the SAI in relation to the study hypothesis.

Table3.Awareness of God Scale and Formal Discipleship Curriculum

\begin{tabular}{llllll}
\hline $\begin{array}{l}\text { Have you at any one time gone } \\
\text { through a formal discipleship } \\
\text { curriculum (new believer's class) }\end{array}$ & & Mean & T Statistic & F. Statistic & P. value \\
& 208 & 2.9810 & 14.014 & 218.354 & 0.000 \\
$\begin{array}{l}\text { No, I have not been } \\
\text { Yes, I have been }\end{array}$ & 330 & 1.7561 & & & \\
\hline
\end{tabular}

Participation in formal discipleship curriculum was measured in relation to the awareness scale as presented in table 3. It is evident that the majority of the participants had gone through a formal discipleship curriculum which was likely to increase their spiritual transformation. Those participants who affirmed the assertion that they had gone through a formal discipleship curriculum were 330 while only 208 disagreed. The results of the analysis produced (a $\mathrm{t}_{(536)}=14.014, \mathrm{p}=0.000$ ), the value was less than 0.05 and therefore the authors rejected the hypothesis implying that there were significant differences in spiritual transformation between members of Redeemed Gospel Churches in Kangundo Sub County who had gone through a formal discipleship curriculum and those who had not.

Table 4.Disappointment with God Scale and Formal Discipleship Curriculum

\begin{tabular}{llllll}
\hline $\begin{array}{l}\text { Have you at any one time gone } \\
\text { through a formal discipleship }\end{array}$ & & Mean & T Statistic & F. Statistic & P. value \\
curriculum (new believer's class) & & & & & \\
& 208 & 2.9210 & 10.734 & 113.883 & 0.000 \\
$\begin{array}{l}\text { No, I have not been } \\
\text { Yes, I have been }\end{array}$ & 328 & 1.8044 & & & \\
\hline
\end{tabular}

With relation to the Disappointment with God Scale, participation in a formal discipleship curriculum was tested and findings presented in table 4 . The study revealed that majority of the participants had gone through a formal discipleship curriculum which was likely to increase their spiritual transformation. The results of the analysis produced a $\left(\mathrm{t}_{(534)}=10.734, \mathrm{p}=0.000\right)$, a p-value that was less than 0.05 and therefore the authors rejected the hypothesis. This implies that there were significant differences in spiritual transformation between members of Redeemed Gospel Churches in Kangundo Sub-County, Machakos County who had gone through a formal discipleship curriculum and those who had not. 


\section{Table 5. Grandiosity Scale and Formal Discipleship Curriculum}

\begin{tabular}{llllll}
\hline $\begin{array}{l}\text { Have you at any one time gone } \\
\text { through a formal discipleship }\end{array}$ & & Mean & T Statistic & F. Statistic & P. value \\
curriculum (new believer's class) & & & & & \\
& 208 & 3.1277 & 11.194 & 27.362 & 0.000 \\
No, I have not been & 330 & 2.0424 & & & \\
Yes, I have been & & & & & \\
\hline
\end{tabular}

The study also measured participation in a formal discipleship curriculum in relation to the Grandiosity Scale. The results in Table 5 reveal that majority of the participants had gone through a formal discipleship curriculum which was likely to increase their spiritual transformation. The results of the analysis produced a the result: $\left(\mathrm{t}_{(536)}=11.194\right.$, $\mathrm{p}=0.000$ ), a value that was less than 0.05 and therefore the hypothesis was rejected implying that there were significant differences in spiritual transformation between members of Redeemed Gospel Churches in Kangundo Sub-County, Machakos County who had gone through a formal discipleship curriculum and those who had not.

Table 6. Instability Scale and Formal Discipleship Curriculum

\begin{tabular}{llcccc}
\hline $\begin{array}{l}\text { Have you at any one time gone } \mathrm{n} \\
\text { through a formal discipleship }\end{array}$ & & Mean & T Statistic & F. Statistic & P. value \\
curriculum (new believer's class) & & & & & \\
& 208 & 3.1907 & 11.859 & 38.234 & 0.000 \\
No, I have not been & 330 & 2.1458 & & & \\
Yes, I have been & 230 & & & \\
\hline
\end{tabular}

With relation to the Instability Scale and participation in a formal discipleship curriculum, table 6 reveals that majority of the participants had gone through a formal discipleship curriculum which was likely to increase their spiritual transformation. The results of the analysis produced a $\left(\mathrm{t}_{(536)} 11.859, \mathrm{p}=0.000\right)$, a value that was less than 0.05 and therefore rejecting the hypothesis. This implied that there were significant differences in spiritual transformation between members of Redeemed Gospel Churches in Kangundo Sub County, Machakos County who had gone through a formal discipleship curriculum and those who had not.

Table 7.Impression Management Scale and Formal Discipleship Curriculum

\begin{tabular}{llllll}
\hline $\begin{array}{l}\text { Have you at any one time gone } \mathrm{n} \\
\text { through a formal discipleship }\end{array}$ & Mean & $\begin{array}{l}\text { T. } \\
\text { curriculum (new believer's class) }\end{array}$ & & Statistic & \\
& & & & & \\
& 208 & 3.4692 & 8.512 & 11.708 & 0.000 \\
No, I have not been & 330 & 2.6212 & & & \\
Yes, I have been &
\end{tabular}

The participants were also asked if they had attended formal discipleship and this was tested against the Impression Management Scaleand Table 7 reveals that majority of the participants had gone through a formal discipleship curriculum which was likely to increase their spiritual transformation. The results of the analysis produced $\left(\mathrm{t}_{(536)}=\right.$ 8.512, $\mathrm{p}=0.001$ ), a value that was less than 0.05 leading to rejection of the hypothesis. This was an implication that there were significant differences in spiritual transformation between members of Redeemed Gospel Churches in Kangundo Sub-County, Machakos County who had gone through a formal discipleship curriculum and those who had not.

Table8. Realistic Acceptance Scale and Formal Discipleship Curriculum

\begin{tabular}{|c|c|c|c|c|c|}
\hline $\begin{array}{l}\text { Have you at any one time gone } \\
\text { through a formal discipleship } \\
\text { curriculum (new believer's class) }\end{array}$ & $\mathrm{N}$ & Mean & $\begin{array}{l}\mathrm{T} . \\
\text { Statistic }\end{array}$ & F. Statistic & P. value \\
\hline $\begin{array}{l}\text { No, I have not been } \\
\text { Yes. I have been }\end{array}$ & $\begin{array}{l}208 \\
330\end{array}$ & $\begin{array}{l}2.8695 \\
16273\end{array}$ & 12.610 & 208.673 & 0.000 \\
\hline
\end{tabular}

With relation to the Realistic Acceptance Scale and participation in a formal discipleship curriculum, table 8 reveals that majority of the participants had gone through a formal discipleship curriculum which was likely to increase their 
spiritual transformation. The results of the analysis produced $\left(\mathrm{t}_{(536)}=12.610, \mathrm{p}=0.000\right)$; a value that was less than 0.05 and therefore the authors rejected the hypothesis implying that there were significant differences in spiritual transformation between members of Redeemed Gospel Churches in Kangundo Sub County, Machakos County who had gone through a formal discipleship curriculum and those who had not.

In summary, when formal discipleship curriculum was statistically tested against the six spirituality subscales to establish the possibility of differences existing between the means of those discipled and those who were not. The analysis found that in all these six variables that there were statistically significant differences in spiritual transformation between members of Redeemed Gospel Churches in Kangundo Sub-County who had been discipled using formal discipleship curriculum and those who were not.

The results of the analysis in 5 subscales gave a p-value of 0.000 with an exception of Impression Management which gave p-value of 0.001 . These were all less than 0.05 , the null hypothesis was therefore rejected and a conclusion made that there were significant differences in spiritual transformation between members of Redeemed Gospel Churches of Kangundo Sub County, Machakos County who had been discipled through formal discipleship curriculum and those who had not.

The study hypothesis that stated: 'there are no significant differences in spiritual transformation among the members who have gone through a formal discipleship curriculum (new believers' class) and those who have not was rejected. The authors noted the fact that the majority of the members had gone through a formal discipleship curriculum but a big number (208 which is almost 38\%) had not. This number should be of great concern to the church. Ogden (2003, p. 40) describes the primary job of church leaders as that of equipping the saints for the work of the ministry in line with scripture in Ephesians 4:11-13. He says that if the leaders fulfil this role, positive consequences such as the body of Christ being built up, members attaining unity in the faith, being grounded in the knowledge of Jesus, the church growing to maturity and attaining the full measure of Christ, will follow.

Discipleship of church members seems to be a neglected area in church circles today leading to a lack of spiritual transformation among professing Christians. Researchers, especially from the West $[8,11,4]$, have identified the teaching ministry of the church as the missing thread that could alleviate the poor state of discipleship in the church according to the instructions of the great commission which requires the church to make disciples and to teach them to obey everything Jesus taught.

\section{Conclusions}

The study findings revealed that the servants of God use Christian education as an approach towards the great commission of God in enhancing spiritual transformation on the faithful. The findings suggest that the church's servant- leaders are working towards strengthening spirituality through the teaching ministry but need to do more to reach those who have not gone through the formal training programs in the church. The teaching ministry of the church, therefore, was confirmed, through this study, to having an influence on the spiritual transformation of Redeemed Gospel Church members.

\section{Recommendations}

1. Given that Christian education is an education in its own right with spiritual transformation as the learning outcome, mechanisms for assessing spiritual transformation need to be implemented.

2. The church should develop a formal discipleship curriculum purposely for the new believers and make it accessible to all. This will give them an opportunity to learn about Christian life and how one is expected to live.

3. An intentional discipleship curriculum that focuses on the strategies that enhance spiritual transformation is required for the training of pastors and church leaders.

\section{References}

[1]. Easum, B., (2015). Radical discipleship is what we need. The effective church group https//:effectivechurch.com.

[2]. Wallace, J. W. (2014). Why discipleship is critical to Christian survival. Cold case Christianity.com.

[3]. Maura, M., Otieno, K., Mbugua, \&Piper, J. (2012). Gaining the world and losing the soul. Nairobi: African Christian Text books. 
[4]. Willard, D. (2006). The great omission: Rediscovering Jesus essential teaching on discipleship. New York: HarperCollins.

[5]. Willard, D. (2009). The great omission: Rediscovering Jesus essential teaching on discipleship (2nd Ed). New York: HarperCollins.

[6]. Wilhoit, J. (1991). Christian education and search for meaning. Grand Rapids, Michigan: Baker Book House.

[7]. Kile, A. (2010). Imitating Christ Jesus as a model in cognitive learning theory. SBL Annual meeting papers November 10. Psychology and biblical studies section: Society of biblical literature.

[8]. Ogden, G. (2003). Transforming Discipleship: Making disciples a few at a time. Dawners Grove: IVP BOOKS.

[9]. Lifeway research (2009) 2008 Assemblies of God discipleship survey results. Lifeway: Lifeway Christian Resources April 162009.

[10]. Habermas, R., \&Issler, K. (1992).Teaching for reconciliation. Grand Rapids: Michigan, Baker Book House.

[11]. Barna, G. (2001). Growing true disciples: Strategies for producing genuine followers ofChrist. Colorado: Water Book press

[12]. Downs, (1994), Teaching for spiritual growth: Introduction to Christian education. Grand Rapids Michigan: Zondervan Publishing House

[13]. Bandura, A.(1976). Social learning theory. New Jersey: Prentice-Hall Inc.

[14]. Yount, W. (1999).Called to teach: An introduction to the ministry of teaching. Nashville Tennessee: Broadman and Holman Publishers.

[15]. Bandura (2003). On the psychological impact and mechanisms on spiritual modelling.International Journal for the Psychology of Religion, 13(3), 167-173.

[16]. Oman, D., \&Thoresen, C. E.(2003).Spiritual modelling: A key to spiritual and religious growth? The International Journal of for the Psychology of Religion 3(3),149-165.

[17]. Gay, Mills and Airasian (2006)Educational Research: Competencies for analysis and applications. New Jersey: Pearson

[18]. Creswell, J.W.(2002). Educational research: Planning, conducting, and evaluating quantitative and qualitative research. Upper Saddle River, Merill: Prentice Hall

[19]. Best and Khan (2003) Research in Education 9th edition. New Delhi: Prentice Hall. 